\title{
SERVICE QUALITY AS TRAVEL AGENCIES BUSINESS IMPROVEMENT FACTOR
}

\author{
Dragana llić1, \\ Lukrecija Đeri², \\ Predrag Stamenković1, \\ Snežana Milićević ${ }^{3}$
}

${ }^{1}$ Higher Business School of Vocational Studies,

Leskovac, Serbia

2 University of Novi Sad, Faculty of Sciences,

Novi Sad, Serbia

${ }^{3}$ University of Kragujevac, Faculty of Hotel Management and Tourism in Vrnjačka Banja, Vrnjačka Banja, Serbia

\begin{abstract}
:
Travel agencies play a very important role in the tourism market. Contribution of travel agencies is a result of the role that they have in tourist traffic and travel facilitation. They appear as mediators between tourists that require a range of services and business entities that provide those services. Their main task is, therefore, to connect a large number of subjects on the tourism demand side and a number of entities (public and private sector) on the supply side. One of the key factors in achieving and maintaining the competitive advantage of travel agencies in the market is a high quality of services which provided tourist satisfaction. Travel agencies can achieve a competitive advantage by providing complete and continuous quality of service. Only those travel agencies that meet the expectations and demands of tourists in terms of the quality of services will be able to retain the existing and attract new tourists. In modern times, therefore, the quality is a key factor for the survival of travel agencies in the market. The aim of this paper is to emphasize the importance of quality of services for the improvement of the overall business operations of travel agencies.
\end{abstract}

Keywords

quality, services, travel agencies.

\section{INTRODUCTION}

Travel agencies play an important role in the tourism market. They largely contribute to tourism becoming the mass phenomenon. Travel agencies have a role of a mediator between tourism demand and tourism supply. Their main task is the travel facilitation and provision of assistance in the organization and implementation of tourist travel. The business success of travel agencies largely depends on the quality of services they offer. The aim of this paper is to highlight the importance of quality and improve the quality of services of travel agencies. This paper shows the results of the survey related to perceptions of service users of travel agencies on the quality of these services, as well as their expectations when it comes to the quality of services of travel agencies in Leskovac. The survey was conducted in order to identify and describe the factors that are important for assessing the quality of services of tourism agencies from the aspect of users of these services and considerations of the options for improving the quality of services of travel agencies in Leskovac. 
QUALITY OF SERVICE AS A BASIS FOR REACHING COMPETITIVE ADVANTAGE OF TRAVEL AGENCIES

There are numerous travel agencies in today's tourism market that have the same or similar offer of travel arrangements. On the other hand, tourists have diverse and complex needs and demands. To achieve these requirements and satisfy the needs of tourists, it's necessary for travel agencies to offer a wide range of products / services of high quality, in the place of sale / purchase of travel arrangements, during the travel and at the destination. Only those travel agencies that meet the expectations and demands of tourists in terms of quality of services will be able to retain the existing and attract new tourists. The quality of services of travel agencies was assessed in different organizations and travel agencies. The quality of services of travel agencies is what distinguishes a successful travel agency from others. The tourists form their perception of the quality of service of a travel agency before travel, during travel, during their stay at the destination and after return from trip. One of the key factors in achieving and maintaining competitive advantage of travel agencies in the market is a high quality of services provided and customer satisfaction. In modern terms, therefore, the quality is a key factor for survival of travel agencies in the market. Competitive advantage can be achieved by providing a complete and continuous service quality. What complicates the perception of service quality is related to the fact that personal attitudes towards quality play an important role. In fact, what one consumer experiences as a superior quality, another user might experience as an average quality (Marinković et al., 2013, p. 322). The perception of the quality of services stems from the comparisons of the customer expectations and the service provided. Customer satisfaction does not only depend on the quality of service, but also the quality of the delivery process, particularly in relation to quality of performance of the personnel who are in direct contact with consumers (Ćosić, 2010, p. 73). There are different degrees of perception, since dissatisfaction with the quality of service to the enthusiastic of delivered service. The low level of service quality is in the case when the user is dissatisfied with the service provided. If the quality of services is at the expected level, then a user is on the threshold of satisfaction, because he received the expected quality. The obtained quality of service is above expectations, and is achieved by full satisfaction of users. In the first case, it's about the conflicting quality of service with the requirements and expectations of users. In the second case, it's about the harmonized quality of service. In the third case, it's about the attractive quality of services by that exceeds users' expectations (Barjaktarović, 2013, p. 197). In the travel agencies, the human factor has a very important role. Employees in travel agencies represent a live element of the work process, they are in direct contact with the actual and potential tourists and business partners, create travel arrangements and other services that are the subject of their business. The success of travel agencies largely depends on the ability, eligibility, and kindness of employees who create, sell and participate in the execution of tourist arrangements. In the process of creation and delivery of tourism products and services, employees represent only one grummet. The second, also very important grummet, are service users, whose assessment of the quality of those services is very important. Their ideas, suggestions, objections should represent the starting point for managers in decision making in the process of creating and delivering tourism services. The users of services, therefore, can largely contribute to improving the quality of tourist services. The quality of services of travel agencies should be viewed from the aspect of users, because user satisfaction is the only real measure of the quality of services. A very important segment of business of travel agencies are promotional activities of tourism products and services. In this segment, omissions in ethical standards can have very unfavorable effects and a negative impact on the image of tourist agencies. All kinds of promotional activities must give users the real image about the tourist product and must not mislead users. Tourist workers are obliged to provide quality, clear and credible information to potential users of tourist products and services. Hideaway of the important characteristics of tourist products and services, untrue information or refusal to provide the requested information represent unethical behavior.

\section{ASSESSMENT OF THE QUALITY OF SERVICES OF TRAVEL AGENCIES IN LESKOVAC FROM THE ASPECT OF TOURISTS}

The following text shall present the results of a survey on the expectations and perceptions of service users of travel agencies in Leskovac about the quality of services of travel agencies. The survey was conducted in November and December 2015. The results of the research can be useful to managers and employees in travel agencies and contribute to the advancement of business through the adjustment of offer of tourism products and services to meet the needs of tourists. In order to investigate the attitudes of tourists about the quality of supply and services of travel agencies in Leskovac, the survey was conducted on a sample of 200 respondents. Primary data 
collection was conducted on the territory of Leskovac. Data were collected by means of a questionnaire specially drawn up for this survey. The questionnaire, in addition to the issues related to gender, age and height of the total annual revenue, includes the issues related to the assessment of the quality of offer of service of travel agencies before (when choosing travel arrangements), during and after travel. The subject of this research is the assessment of the degree of satisfaction or dissatisfaction of service users with various aspects of the tourist offer and the quality of services of travel agencies in Leskovac. Thus, the subject of the research determines the task of the research, and that is:

- Assessment of the factors that influence the selection of a travel agency for the organization and realization of the travel;

- Assessment of the factors that influence the choice of travel arrangements;

- Assessment of dedication, efficiency, kindness and expertise of employees in travel agencies in Leskovac;

- Assessment of organization of space of travel agencies (interior)

- Assessment of the factors necessary for successful realization of travel;

- Consideration of the relationship between price and quality of services for the travel arrangement;

- Consideration of the relationship between the expected and obtained quality.

The aim of the research is to assess, identify and describe the factors that are important for assessing the quality of services of travel agencies from the aspect of users of these services, as well as to consider the possibilities for improving the quality of services of travel agencies in Leskovac, through recognition of ideas, processes and procedures that will contribute to improving the quality of services.

Tourists, users of services of travel agencies in Leskovac, had the opportunity to assess:

Factors which affect the choice of a travel agency, such as:

- Their own positive experience;

- Recommendation from friends, relatives, colleagues;

- The image of a travel agency;

- The offer of travel agency (attractive travel arrangements);

- Price of travel arrangements;

Factors which relate to the travel agency, such as:

- Internet pages;

- The interior of the travel agency;
- Professionalism, efficiency and kindness of employees in travel agencies;

- The attractiveness of travel arrangements;

Factors which are important for the choice of travel arrangements, such as:

- Previous experience;

- Recommendations from friends, relatives, colleagues;

- Recommendation from the travel agent;

- Price of travel arrangements.

The engagement of tourist guides during the trip as well as whether they:

- Respect the plan of schedule of passengers in the bus;

- Respect the travel itinerary;

- Provide information to passengers during the trip;

- Perform operational and technical tasks during the trip;

- Provide information to passengers about any changes in the program of the trip.

\section{THE ANALYSIS AND INTERPRETATION OF RESEARCH RESULTS}

The technique used herein for data collection is a questionnaire. In the questionnaire, in addition to the issues related to the demographic characteristics of the respondents (gender, age, education level, total annual revenues), there are 24 questions formulated in the form of five degrees of Likert scales.

Table 1. Gender of respondents

Gender Number Percent (\%)
Male
82
41

$\begin{array}{lll}\text { Female } & 118 & 59\end{array}$

Total

200

100.0

Source: Authors' research based on the analysis of data in SPSS 20.

If we look at the gender of respondents in a sample of 200 respondents, 82 were men (41\%) and 118 women (59\%) (see Table 1). 
The research results show that the services of travel agencies in Leskovac are most used by respondents aged from 20 to 29 years (35\%), followed by the respondents aged from 30 to 39 years (33\%) (see Table 2). The figures for the age of participants were as follows:

- $3 \%$ of respondents aged up to 19 years;

- $35 \%$ of respondents aged from 20 to 29 years;

- $33 \%$ of respondents aged from 30 to 39 years;

- $18 \%$ of respondents aged from 40 to 49 years;

- $8.5 \%$ of respondents aged from 50 to 59 years;

- $2.5 \%$ of respondents aged over 60 years.

In relation to the level of education of the respondents, those with higher education (65\%) were prevailing. The services of a travel agency in Leskovac are used by $17.5 \%$ of respondents with secondary education. Moreover, $12.5 \%$ of respondents with a master's degree and $3.5 \%$ of respondents with a doctoral degree have assessed the quality of services of travel agencies in Leskovac (see Table 3).

Table 2.The age structure

\begin{tabular}{ccc}
\hline Age & Number & Percent (\%) \\
\hline To 19 & 6 & 3 \\
\hline $20-29$ & 70 & 35 \\
\hline $30-39$ & 66 & 33 \\
\hline $40-49$ & 36 & 18 \\
\hline $50-59$ & 17 & 8.5 \\
\hline 60 and more & 5 & 2.5 \\
\hline Total & 200 & 100.0 \\
\hline
\end{tabular}

Source: Authors' research based on the analysis of data in SPSS 20

Table 3. The level of education of respondents

\begin{tabular}{ccc}
\hline The level of education & Number & Percent $(\%)$ \\
\hline Primary school & 3 & 1.5 \\
\hline Secondary school & 35 & 17.5 \\
\hline High education & 130 & 65 \\
\hline Master & 25 & 12.5 \\
\hline Doctorate & 7 & 3.5 \\
\hline Total & 200 & 100.0
\end{tabular}

Source: Authors' research based on the analysis of data in SPSS 20
The respondents of different ages differently assess the level of agreement with the factors affecting the choice of the travel agency which will organize and realize their trip. The respondents have assessed the level of agreement with certain factors across the five degrees of Likert scales (Strongly disagree; I do not agree; I have not attitude; I agree; I totally agree).

Respondents of all ages fully agree that the price of arrangements offered by travel agencies most influence the choice of tourist agencies that will organize and realize their trip.

As for other factors affecting the selection of a travel agency, the respondents of different age have differently estimated the degree of compliance with these factors, as shown below.

Respondents up to 19 years of age pointed out that they choose travel agency:

- according to their experience when it comes to previous travels;

- based on the recommendation from a friend, relative, colleague.

Respondents aged 20 to 29 years pointed out that they choose travel agency:

- according to the offer of travel agencies (attractive travel arrangements);

- according to their experience when it comes to previous travels;

- according to the image of a travel agency;

- based on the recommendation from a friend, relative, colleague.

Respondents aged 30 to 39 years pointed out that they choose a travel agency:

- according to their experience when it comes to previous travels;

- according to the offer of travel agencies (attractive travel arrangements);

- according to the image of a travel agency;

- based on the recommendation from a friend, relative, colleague.

Respondents aged 40 to 49 years pointed out that they choose a travel agency:

- according to their experience when it comes to previous travels;

- according to the image of a travel agency;

- based on the recommendation from a friend, relative, colleague;

- according to the offer of travel agencies (attractive travel arrangements). 
Respondents aged 50 to 59 years pointed out that they choose a travel agency:

- according to their experience when it comes to previous travels;

- according to the image of a travel agency;

- according to the offer of travel agencies (attractive travel arrangements);

- based on the recommendation from a friend, relative, colleague.

Respondents aged 60 and over pointed that they choose a travel agency:

- based on the recommendation from a friend, relative, colleague;

- according to the image of a travel agency;

- according to their experience when it comes to previous travels;

- according to the offer of travel agencies (attractive travel arrangements).

The following lines show how the respondents with different levels of education have assessed each of the factors in the selection of a travel arrangement. The respondents have assessed the importance of a certain factor across five degrees of Likert scales (completely not important; does not important; neutral; important; very important).

All respondents have highlighted the price of a travel arrangement (very important) as an important factor in the choice of a travel arrangement (very important).

As for other factors affecting the selection of a travel arrangement, the respondents of different level of education have differently estimated these factors, as shown below.

The largest number of respondents with a secondary education qualification considers the following segments relevant for the choice of travel arrangements:

- A recommendation from a travel agent;

- Previous experience when it comes to choice of a travel arrangement;

- A recommendation from a friend, relative, colleague.

The largest number of respondents with a higher education qualification considers the following segments relevant for the choice of travel arrangements:

- A recommendation from a travel agent;

- Previous experience when it comes to choice of a tourist arrangement;

- A recommendation from a friend, relative, colleague.
The largest number of respondents with a master's degree consider the following segments relevant for the choice of travel arrangements:

- A recommendation from a friend, relative, colleague;

- Previous experience when it comes to choice of a travel arrangement;

- A recommendation from a travel agent.

The respondents with a doctoral degree consider the following segments relevant for the choice of travel arrangements:

- A recommendation from a travel agent;

- Previous experience when it comes to the choice of a travel arrangement;

- A recommendation from a friend, relative, colleague.

Respondents of all age groups agree with the fact that the quality of services of travel arrangements offered by travel agencies in Leskovac positively correlates with the price of those services, that the expected quality is in accordance with the received quality, and that the terms of payment for travel arrangements are acceptable.

\section{CONCLUSION}

The quality of services of travel agencies is what distinguishes successful tourist agencies from others. One of the key factors for achieving and maintaining the competitive advantage of travel agencies in the market is a high quality of services provided and high level of customer satisfaction. In modern terms, therefore, the quality is the key factor for survival of travel agencies in the market. Competitive advantage can be achieved by providing the complete and continuous quality of services. The respondents of all age groups fully agree that the price arrangements offered by travel agencies in Leskovac greatly impact the choice of travel agencies that will organize and realize their trip. As for other factors affecting the selection of a travel agency, the respondents belonging to different age groups differently estimated the degree of compliance with these factors. All respondents have listed the price of travel arrangements as the factor that has the greatest impact on the choice of travel arrangements. As for other factors affecting the choice of a travel arrangement, the respondents of different level of education have differently assessed these factors. The respondents of all age groups agree with the fact that the quality of travel arrangements offered by travel agencies in Leskovac is in accordance with the price of those services, that the expected quality is in accordance with the received quality, and that the terms of payment are acceptable for travel arrangements. 


\section{REFERENCES}

Barjaktarović, D. (2013). Upravljanje kvalitetom u hotelijerstvu. Beograd: Fakultet za turistički i hotelijerski menadžment.

Ćosić, M. (2010). Upravljanje kvalitetom turističkih usluga. Beograd: Visoka turistička škola strukovnih studija.

Marinković, V., Senić, V., \& Dimitrovski, D. (2013). Merenje stavova potrošača o kvalitetu usluga u restoraterstvu. Teme: časopis za društvenu teoriju i praksu, 37(1), 319-338.

Rajković, D. (2010). Kvalitet i QMS turističke agencije. Retrieved September 19, 2016 from http://www. kvalitet.org.rs/

Rajković, D., \& Milićević, I. (2007). Kvalitet usluga turističke agencije. Festival kvaliteta: 34 . Nacionalna konferencija o kvalitetu, Kragujevac 8-11. maj 2007. Retrieved September 19, 2016 from http://www. cqm.rs/2007/pdf/34/52.pdf
Spasić, V. (2011). Poslovanje turističkih agencija i organizatora putovanja. Beograd: Univerzitet Singidunum

Stanković, M. (2008). Menadžment kvalitetom turističke agencije. Festival kvaliteta: 35 . Nacionalna konferencija o kvalitetu, Kragujevac 13-15. maj 2007. Retrieved September 19, 2016 from http://www.cqm. rs/2008/pdf/35/24.pdf

Veselinović, S., \& Rajković, D. (2010). ISO 9001:2008 u poslovanju turističke agencije. 6. Naučni skup sa međunarodnim učešćem, Sinergija 2010. Retrieved September 19, 2016 from http://www.singipedia. singidunum.ac.rs/content/370-ISO-9001-2008-uposlovanju-turisticke-agencije

Živković, R., \& Šećković, S. (2008). Istraživanje kvaliteta usluga turističke agencije. Singidunum revija, 5(2), 120-127. 